\title{
Oral corticosteroids for asthma exacerbations might be associated with adrenal suppression: Are physicians aware of that?
}

\author{
Cristina B. Barra ${ }^{1}$, Maria Jussara F. Fontes ${ }^{2}$, Marco Túlio G. Cintra ${ }^{3}$, Renata C. Cruz ${ }^{3}$, Janaína A. G. Rocha ${ }^{3}$, \\ Maíla Cristina C. Guimarães ${ }^{3}$, Ivani Novato Silva ${ }^{1 *}$

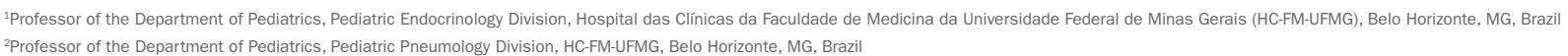

Study conducted at Endocrinology and Pneumology Division, Department of Pediatrics, Faculdade de Medicina/ Hospital das Clínicas, Universidade Federal de Minas Gerais (UFMG), Belo Horizonte, MG, Brazil

Article received: $12 / 8 / 2016$ Accepted for publication: $2 / 5 / 2017$

*Correspondence: Divisão de Endocrinologia Infantil e do Adolescente Departamento de Pediatria, Faculdade de Medicina/Hospital das Clínicas - UFMG Address: Av. Alfredo Balena, 190, sala 267 Belo Horizonte, MG - Brazil Postal code: 30130-100 ivanins@medicina.ufmg.br

http://dx.doi.org/10.1590/1806-9282.63.10.899

\section{SUMmARY}

Introduction: Oral corticosteroids (OCS) are a mainstay of treatment for asthma exacerbations, and short-term OCS courses were generally considered to be safe. Nevertheless, frequent short-term OCS courses could lead to hypothalamicpituitary-adrenal (HPA) axis dysfunction. Our study aimed at investigating the integrity of the HPA axis in children with persistent asthma or recurrent wheezing at the beginning of an inhaled corticosteroids (ICS) trial.

Method: Morning basal cortisol was assessed just before the beginning of ICS, and 30, 60, and 90 days later, using Immulite ${ }^{\circledR}$ Siemens Medical Solutions Diagnostic chemiluminescent enzyme immunoassay (Los Angeles, USA; 2006). Results: In all, 140 children (0.3-15 years old) with persistent asthma or recurrent wheezing have been evaluated and $40 \%$ of them reported short-term OCS courses for up to 30 days before evaluation. Out of these, $12.5 \%$ had biochemical adrenal suppression but showed adrenal recovery during a three-month ICS trial treatment. No significant differences were observed among children with or without adrenal suppression, neither in the number of days free of OCS treatment before cortisol evaluation $(\mathrm{p}=0.29)$ nor in the last OCS course duration $(\mathrm{p}=0.20)$. The number of short-term OCS courses reported in the year preceding the cortisol evaluation was also not different $(\mathrm{p}=0.89)$.

Conclusion: Short-term systemic courses of corticosteroids at conventional doses can put children at risk of HPA axis dysfunction. ICS treatment does not impair adrenal recovery from occurring. Health practitioners should be aware of the risk of a blunted cortisol response upon exposure to stress during the follow-up of patients with persistent asthma or recurrent wheezing.

Keywords: asthma, corticosteroids, suppression, child.

\section{INTRODUCTION}

Corticosteroids are a mainstay of treatment for asthma and in conjunction with inhaled short-acting beta $a_{2}$-agonists (SABA) are responsible for lower children hospitalization rates during flare-ups. ${ }^{1}$

Short-term oral corticosteroids (OCS) courses used in asthma exacerbations are normally considered to be safe and the possibility of adrenal failure was disregarded. ${ }^{2}$ But children who recurrently visit a health care provider and require multiple OCS courses may have hypothalamic-pituitary-adrenal (HPA) axis dysfunction. ${ }^{3}$
Baseline cortisol measurements are classically performed to confirm the integrity of the HPA axis response in several clinical situations, such as suspected adrenal suppression (AS). Morning basal cortisol assessment is a simple, inexpensive method with good correlation with serum cortisol after corticotropin-releasing hormone (CRH) stimulus and could be a screening tool in children with asthma at risk of AS after corticosteroid withdrawal. ${ }^{4-6}$

The study aimed at investigating the integrity of the HPA axis in children with persistent asthma and infants 
with recurrent wheezing at the beginning of a first inhaled corticosteroids (ICS) trial.

\section{Method}

This four-year prospective study was approved by the Research Ethics Committee of Federal University of Minas Gerais (UFMG), in Belo Horizonte, Brazil. The children, adolescents and legal guardians agreed to participate and signed an informed written consent after receiving all pertinent information.

Participants were enrolled in a large Public Health Program for asthma control in Belo Horizonte, Brazil. The program is a partnership between UFMG and the Brazilian public health system (SUS, in the Portuguese acronym), which provides controller treatment according to The Global Strategy for Asthma Management and Prevention: ${ }^{7}$ ICS (beclomethasone dipropionate CFC with a spacer at daily doses of 100-200 mcg), inhaled bronchodilator SABA and OCS as needed (prednisone at $1-2 \mathrm{mg} / \mathrm{kg}$ ). As part of the treatment, training for the children's parents/guardians or carers and information on environmental control were also provided.

Recurrent wheezing infants and children with persistent asthma who have been referred for ICS controller therapy trial were randomly recruited for a cross-sectional investigation of HPA axis integrity. Subjects who have previously received ICS or presented any other chronic disease that could interfere with adrenal function were not included.

Morning cortisol level was assessed just before the beginning of ICS and 30, 60 and 90 days later. Following overnight fasting, blood samples were collected between 7:00 and 8:00 a.m., processed at the Hospital das Clínicas (HC) UFMG Laboratory Medical Service and evaluated using Immulite Siemens Medical Solutions Diagnostic chemiluminescent enzyme immunoassay, Los Angeles USA, 2006. Lab work results were presented in $\mathrm{mcg} / \mathrm{dL}$ (conversion factor: $\mathrm{nmol} / \mathrm{L}=\mathrm{mcg} / \mathrm{dL} \times 27.59$ ). The participants' basal serum cortisol levels were analyzed according to the manufacturer's data. The manufacturer's range is $5-25 \mathrm{mcg} / \mathrm{dL}$, the detection limit (sensitivity) is $>0.2 \mathrm{mcg} / \mathrm{dL}$ and the working range is $1-50 \mathrm{mcg} / \mathrm{dL}$.

At each visit, all participants filled out a clinical data form.

\section{Statistical analysis}

Descriptive statistics were performed, and the data were presented as measures of central tendency and dispersion (median and mean $\pm \mathrm{SD}$ ) for continuous variables and as proportions for categorical and quantitative variables.
Chi-square or Fisher exact test were used to evaluate the association between categorical variables. To compare numeric variables between independent groups, Student's t-test or Kruskal-Wallis test was used. A 95\% confidence interval was calculated using the Fleiss quadratic method. The statistical package Software EpiInfo version 6.04 was used; differences were considered significant at $\mathrm{p}<0.05$ for all analyses.

\section{Results}

One hundred and forty (140) children, $60.7 \%$ male, with a median age of $2.5(0.3-15)$ years were included in the study.

Ninety-six patients $(96,68.6 \%)$ reported short-term OCS courses in the past 12 months, and 56 of them received an OCS course for up to 30 days before the evaluation. The distribution of morning cortisol levels according to a reference range and follow-up characteristics are presented in Table 1.

Seven out of the 56 children (12.5\%) showed suppressed morning basal cortisol (<5 mcg/dL): median of 2.6 (1.6-4.9) $\mathrm{mcg} / \mathrm{dL}$. They were all male subjects with a median age of 1 (0.3-4.6) year, and didn't present signs or symptoms of adrenal insufficiency. The $87.5 \%$ remaining children $(\mathrm{n}=49)$ aged $2.7(0.3-15)$ years presented a median morning basal cortisol within the reference range: $12.8(5.2-25.8) \mathrm{mcg} / \mathrm{dL}$. The serum cortisol of these two groups of children showed a statistical significant difference ( $\mathrm{p}<0.0001)$.

The parents/guardians reported $2.8 \pm 2.0$ short-term OCS courses for the whole group in the 12 months preceding the cortisol evaluation. No statistically significant differences were observed neither in the number of days free of OCS treatment $(\mathrm{p}=0.29)$ nor in the last OCS course duration $(\mathrm{p}=0.20)$ among patients with low and normal basal cortisol levels. The number of short-term OCS courses reported in the year preceding the evaluation was also not different $(\mathrm{p}=0.89)$ among both groups of children (Table 1).

Adrenal function recovery was observed throughout the 90-day ICS trial period in the seven patients who presented suppressed cortisol levels; they achieved normal values (> $5 \mathrm{mcg} / \mathrm{dL}$ ) within a month. A progressive increase of mean cortisol values was observed in these seven children compared to the results of the other 133 participants with normal adrenal function since the first assessment (Table 2).

Also during the 90-day trial period, we observed a decline of $62.5 \%$ in the need of rescue treatment for patients using ICS: the percentages of OCS use in the first, second and third month of evaluation were 5.6, 3.5 and $2.1 \%$, respectively. During the follow-up, no children presented signs or symptoms of adrenal insufficiency. 
TABLE 1 Basal serum cortisol in asthmatic children and variables related to short-term oral corticosteroid courses before inhaled corticosteroid trial.

\begin{tabular}{lllll} 
& \multicolumn{2}{l}{ Cortisol $(\mathbf{m c g} / \mathbf{d L})^{\mathrm{a}}$} & Statistical test & P-value \\
\hline Group & $<5(\mathrm{n}=07)$ & $\geq 5(\mathrm{n}=49)$ & & 0.0708 \\
\hline Age (years) & $1.0(0.3-4.6)$ & $2.7(0.3-15)$ & $\mathrm{KW}=1.84$ & $<0.0001$ \\
\hline Basal cortisol $^{\mathrm{b}}$ & $2.6(1.6-4.9)$ & $12.8(5.2-25.8)$ & $\mathrm{KW}=18.01$ & 0.20 \\
\hline Duration of last OCS course (days) & $5.7 \pm 2.2$ & $4.6 \pm 2.1$ & $\mathrm{t}=1.31$ & 0.89 \\
\hline Number of OCS courses (last 12 months) & $2.7 \pm 1.4$ & $2.8 \pm 2.0$ & $\mathrm{t}=0.14$ & 0.29 \\
\hline Interval free of OCS courses (days) & $4.0(1-27)$ & $14.0(1-30)$ & $\mathrm{KW}=0.22$ & \\
\hline
\end{tabular}

Reference value $\geq 5 \mathrm{mcg} / \mathrm{dL}$.

${ }^{b}$ Median (range).

OCS: short-term oral corticosteroid.

TABLE 2 Early basal serum cortisol recovery during inhaled corticosteroid trial in 140 asthmatic children.

\begin{tabular}{lllllll} 
& $\mathbf{n}$ & $\begin{array}{l}\text { Cortisol }^{\mathbf{a}} \\
\text { Median (range) }\end{array}$ & $\mathbf{n}$ & \multicolumn{2}{c}{$\begin{array}{l}\text { Cortisol } \\
\text { Median (range) }\end{array}$} & PW \\
\hline Basal & 7 & $2.6(1.6-4.9)$ & 133 & $12.0(5.2-41.6)$ & 27.71 & $<0.0001$ \\
\hline 30 days & 7 & $9.5(1.3-14.6)$ & 92 & $11.3(3.7-26.2)$ & 4.48 & 0.0344 \\
\hline 60 days & 6 & $9.2(3.9-19.8)$ & 77 & $11.6(4.9-27.3)$ & 1.20 & 0.2756 \\
\hline 90 days & 4 & $12.1(10.2-14.4)$ & 46 & $12.6(4.6-35.3)$ & 0.02 & 0.8862 \\
\hline
\end{tabular}

aReference value $\geq 5 \mathrm{mcg} / \mathrm{dL}$.

\section{Discussion}

We investigated the HPA axis integrity of wheezing infants and asthmatic children and adolescents enrolled in a large Public Health Program for asthma control. Short-term OCS courses proved to be related with biochemical adrenal suppression in $12.5 \%$ of them. These results cause concern because systemic corticosteroids are widely used for acute asthma treatment. Children with poor adherence to the maintenance treatment are at major risk.

Adrenal crisis prevalence is unknown and may be quite rare. ${ }^{8}$ Indeed, no signs and symptoms of adrenal crisis after steroid withdrawal such as hypotension, shock, lethargy, unexplained hypoglycemia or seizures have been reported in our series. Nevertheless, adrenal atrophy was described at autopsy in asthmatic children who had been submitted to corticotherapy and presented unexpected deaths. ${ }^{9}$

Adrenal gland hypoplasia and atrophy are preceded by HPA-axis suppression, which in turn has been demonstrated to occur after exposure to courses as short as five-day duration of oral corticotherapy..$^{10}$ It has been described that any subject who has taken $20 \mathrm{mg}$ of prednisone for 5 days or longer is at risk of HPA axis suppression. ${ }^{11}$

As previously shown ${ }^{12}$ and corroborated in our study, HPA axis dysfunction at baseline conditions may already be detected at the very first week after discontinuation of OCS treatment. After corticosteroid withdrawal, central recovery precedes the peripheral recovery but AS may take longer to cure. Prolonged HPA axis suppression has been reported in otherwise asymptomatic adult patients undergoing 14-day steroid treatment for acute exacerbation of chronic obstructive pulmonary disease.${ }^{13}$ And for children presenting other chronic disease, biochemical evaluation at twenty months after OCS withdrawal could reveal a persistent risk of $11 \%$ of AS. ${ }^{14}$

Prolonged AS is more likely to be associated to long durations of OCS treatment and more potent corticosteroids or multiple doses. ${ }^{15,16}$ Mortimer et al. observed that the risk of adrenal failure doubles per corticotherapy course per year. ${ }^{17}$ But this cumulative effect of OCS on AS is not always clear. In our series, the number of OCS courses received in the preceding year was similar among children with or without HPA-axis suppression.

Systemic adverse effects such as AS have been clearly associated with OCS and to a lesser degree with ICS use. ${ }^{12,14-16}$ In asthma controller treatment, side effects due to ICS use may be triggered by many variables such as bioavailability related to dosage, delivery device, particle size and lung versus upper airway deposition. ${ }^{18}$

Evidences of HPA dysfunction due to ICS have been reported in the literature in up to $40 \%^{10,19-23}$ of cases and due to OCS in up to $80 \% .{ }^{24}$ Symptomatic AS can be seen in children treated with inhaled beclomethasone even at initial doses as low as $200 \mathrm{mcg} /$ day, depending on individual sensitivity and genetic predisposition. ${ }^{23}$ 
The Canadian Society of Allergy and Clinical Immunology recommends screening for AS in children receiving high-dose ICS based on morning serum cortisol level. ${ }^{18}$ The current recommendation is to use the lowest effective dose of ICS to maximize the benefit-risk ratio, ${ }^{19}$ but some children will really need high-dose ICS to control asthma symptoms. Among available high-dose ICS drugs and devices, both inhaled beclomethasone dipropionate and fluticasone propionate have a bigger effect on the HPA axis than budesonide due to metabolic issues. ${ }^{25,26}$

It seems that for both OCS and ICS, corticosteroid dose and duration of treatment, despite being important risk factors, are not good predictors of which patients will actually develop adrenal insufficiency. ${ }^{15,16,27}$ Surprisingly, the most reliable predictors of AS described in asthmatic children are related to clinical features such as low body mass for age, ${ }^{28}$ decreased lung function and poor symptom control. ${ }^{29}$

Impaired adrenal function in asthmatic children was believed to contribute to the development of more severe asthma, but current data suggest that asthma itself may down regulate the HPA activity so that ICS treatment may actually improve adrenal function in well-controlled patients. ${ }^{30}$

In our series, biochemical adrenal suppression was resolved in a short period during follow-up both by controlling asthma symptoms with inhaled corticosteroid treatment and by ceasing systemic drug treatments. Therefore, controlling asthma symptoms better could have had an important impact on HPA axis recovering possibly by reducing inflammatory mediators.

Our findings reinforce the idea that treating children with asthma and recurrent wheezing infants during flareups with short-term OCS courses at conventional doses can put them at risk of HPA axis dysfunction. In childhood, in the absence of a good predictive marker or forecast, the most important method to prevent adrenal crisis might be risk awareness and clinical follow-up.

We conclude that short-term systemic courses of corticosteroids at conventional doses were related to biochemical adrenal suppression, which can put children at risk of HPA axis dysfunction. A blunted cortisol response upon exposure to stress could occur after corticosteroid withdrawal and basal cortisol should be promptly assessed in case of any suspicion or presence of symptoms such as fatigue, myalgia and reduced vitality in clinical practice.

\section{AcKnowledgments}

Our research was partially supported by grants from Pró-Reitoria de Pesquisa da UFMG.
The authors would like to thank Cristiane de Freitas Cunha Grillo and Eugênio Marcos Andrade Goulart for their support and assistance.

\section{Conflict Of Interest}

The authors declare no conflict of interest.

\section{Resumo}

Uso de corticosteroides orais nas exacerbações da asma pode estar associado à supressão adrenal: os médicos estão alertas?

Introdução: A corticoterapia oral (CO) é um dos pilares do tratamento na exacerbação da asma, e cursos de curta duração são geralmente considerados seguros. No entanto, crianças submetidas a repetidos cursos estão sujeitas a disfunção do eixo hipotálamo-hipófise-adrenal (HHA).

Objetivo: Investigar a integridade do eixo HHA em crianças com asma persistente ou sibilância recorrente com indicação para corticoterapia inalatória (CI).

Método: Avaliação do cortisol sérico basal antes da introdução da CI e 30, 60 e 90 dias após iniciado o tratamento, utilizando-se o imunoensaio Immulite ${ }^{\circledR}$ Siemens Medical Solutions Diagnostic chemiluminescent (Los Angeles, EUA; 2006).

Resultados: Das 140 crianças avaliadas $(0,3$ a 15 anos de idade) com asma persistente ou sibilância recorrente, $40 \%$ relataram ter recebido CO no último mês antes da avaliação. Cerca de 12,5\% delas apresentaram supressão adrenal bioquímica e evoluíram com recuperação do eixo HHA durante os primeiros três meses em CI. O número de dias livres de $\mathrm{CO}$ e a duração do último curso antes da avaliação do cortisol não foram significativamente diferentes entre as crianças com ou sem supressão adrenal ( $\mathrm{p}=0,29$ e $\mathrm{p}=0,20$, respectivamente). $\mathrm{O}$ número de cursos de curta duração relatados no ano anterior à avaliação também não esteve associado à supressão adrenal $(\mathrm{p}=0,89)$.

Conclusão: A utilização dos corticosteroides nas doses convencionais, em cursos de curta duração, pode colocar as crianças em risco de disfunção do eixo HHA. A recuperação desse eixo é possível durante a CI. Profissionais de saúde devem estar atentos para a possibilidade de resposta inadequada ao estresse durante o acompanhamento de crianças com asma persistente ou sibilância recorrente.

Palavras-chave: asma, corticosteroides, supressão, criança. 


\section{References}

1. Fontes MJ, Affonso AG, Calazans GM, de Andrade CR, Lasmar LM, Nader $\mathrm{CM}$, et al. Impact of an asthma management program on hospitalizations and emergency department visits. J Pediatr (Rio J). 2011; 87(5):412-8.

2. Zora JA, Zimmerman D, Carey TL, O’Connell EJ, Youginger JW. Hypothalamic-pituitary-adrenal axis suppression after short-term, highdose glucocorticoid therapy in children with asthma. Allergy Clin Immunol. 1986; 77(1 Pt 1):9-13.

3. Hasegawa K, Bittner JC, Nonas SA, Stoll SJ, Watase T, Gabriel S, et al.; Multicenter Airway Research Collaboration-37 Investigators. Children and adults with frequent hospitalizations for asthma exacerbation, 2012-2013: a multicenter observational study. J Allergy Clin Imunnol Pract. 2015; 3(5):751-8.e1.

4. Clark DJ, Lipworth BJ. Evaluation of corticotropin releasing factor stimulation and basal markers of hypothalamic-pituitary-adrenal axis suppression in asthmatic patients. Chest. 1995; 112(5):1248-52.

5. Cunha CF, Silva IN, Finch FL. Early adrenocortical recovery after glucocorticoid therapy in children with leukemia. J Clin Endocrinol Metab. 2004; 89(6):2797-802.

6. Woods CP, Argese N, Chapman M, Boot C, Webster R, Dabhi V, et al. Adrenal suppression in patients taking inhaled glucocorticoids is highly prevalent and management can be guided by morning cortisol. Eur J Endocrinol. 2015; 173(5):633-42.

7. The Global Strategy for Asthma Management and Prevention Global Initiative for Asthma (GINA) 2015. Available from: http://ginasthma.org.

8. Bancos I, Hahner S, Tomlinson J, Arlt W. Diagnosis and management of adrenal insufficiency. Lancet Diabetes Endocrinol. 2015; 3(3):216-26.

9. Busuttil A. Adrenal atrophy at autopsy in two asthmatic children. Am J Forensic Med Pathol. 1991; 12(1):36-9.

10. Henzen C, Suter A, Lerch E, Urbinelli R, Schrno XH, Briner VA. Suppression and recovery of adrenal response after short-term, high-dose glucocorticoid treatment. Lancet. 2000; 355(9203):542-5.

11. Axelrod L. Perioperative management of patients treated with glucocorticoids. Endocrinol Metab Clin North Am. 2003; 32(2):367-83.

12. Gordijn MS, Rensen N, Gemke RJ, van Dalen EC, Rotteveel J, Kaspers GJ Hypothalamic-pituitary-adrenal (HPA) axis suppression after treatment with glucocorticoid therapy for childhood acute lymphoblastic leukaemia. Cochrane Database Syst Rev. 2015; 8:CD008727.

13. Schuetz P, Christ-Crain M, Schild U, Süess E, Facompre M, Baty F, et al. Effect of a 14-day course of systemic corticosteroids on the hypothalamicpituitary-adrenal-axis in patients with acute exacerbation of chronic obstructive pulmonary disease. BMC Pulm Med. 2008; 8:1.

14. Huber BM, Bolt IB, Sauvain MJ, Flück CE. Adrenal insufficiency after glucocorticoid withdrawal in children with rheumatic diseases. Acta Paediatr. 2010; 99(12):1889-93.

15. Broesen LH, Pereira AM, Jørgensen JO, Dekkers OM. Adrenal insufficiency in corticosteroids use: systematic review and meta-analysis. J Clin Endocrinol Metab. 2015; 100(6):2171-80.
16. Zazzali JL, Broder MS, Omachi TA, Chang E, Sun GH, Raimundo K. Risk of corticosteroid-related adverse events in asthma patients with high oral corticosteroid use. Allergy Asthma Proc. 2015; 36(4):268-74.

17. Mortimer KJ, Tata LJ, Smith CJ, West J, Harrison TW, Tattersfield AE, et al. Oral and inhaled corticosteroids and adrenal insufficiency: a case-control study. Thorax. 2006; 61(5):405-8.

18. Issa-El-Khoury K, Kim H, Chan ES, Vander Leek T, Noya F. CSACI position statement: systemic effect of inhaled corticosteroids on adrenal suppression in the management of pediatric asthma. Allergy Asthma Clin Immunol. 2015; 11:9.

19. Pandya D, Puttanna A, Balagopal V. Systemic effects of inhaled corticosteroids: an overview. Open Respir Med J. 2014; 8:59-65.

20. Todd GR, Acerini CL, Ross-Russell R, Zahra S, Warner JT, McCance D. Survey of adrenal crisis associated with inhaled corticosteroids in the United Kingdom. Arch Dis Child. 2002; 87(6):457-61.

21. Priftis KN, Papadimitrou A, Gatsopoulou E, Yiallouros PK, Fretzayas A Nicolaidou P. The effect of inhaled budesonide on adrenal and growth suppression in asthmatic children. Eur Respir J. 2006; 27(2):316-20.

22. Ozbek OY, Turktas I, Bakirtas A, Bideci A. Evaluation of hypothalamicpitutitary-adrenal axis suppression by low-dose $(0.5 \mathrm{microg})$ and standarddose (250 microg) adrenocorticotropic hormone (ACTH) tests is asthmatic children with inhaled corticosteroid. J Pediatr Endocrinol Metabol. 2006; 19(8):1015-23

23. Hawcutt DB, Jorgensen AL, Wallin N, Thompson B, Peak M, Lacy D, et al. Adrenal responses to a low-dose short synacthen test in children with asthma. Clin Endocrinol (Oxf). 2015; 82(5):648-56.

24. Aljebab F, Choonara I, Conroy S. Systematic review of the toxicity of shortcourse oral corticosteroids in children. Arch Dis Child. 2016; 101:365-70.

25. Clark DJ, Clark RA, Lipworth BJ. Adrenal suppression with budesonide and fluticasone propionate given by large volume spacer to asthmatic children. Thorax. 1996; 51(9):941-3.

26. Pedersen S, Fuglsang G. Urine cortisol excretion in children treated with high doses of inhaled corticosteroids: a comparison of budesonide and beclomethasone. Eur Respir J. 1988; 1(5):433-5.

27. Smith RW, Downey K, Gordon M, Hudak A, Meeder R, Barker S, et al Prevalence of hypothalamic-pituitary-adrenal axis suppression in children treated for asthma with inhaled corticosteroid. Paediatr Child Health. 2012; 17(5):e34-9.

28. Cavkaytar O, Vuralli D, Arik Yilmaz E, Buyuktiryaki B, Soyer O, Sahiner UM, et al. Evidence of hypothalamic-adrenal-axis suppression during moderate-to-high-dose inhaled corticosteroid use. Eur J Pediatr. 2015; 174(11):1421-31.

29. Zöllner EW, Lombard CJ, Galau U, Hough FS, Irusen EM, Weinberg E. Hypothalamic-pituitary-adrenal axis suppression in asthmatic school children. Pediatrics. 2012; 130(6):e1512-9.

30. Priftis KN, Papadimitriou A, Nicolaidou P, Chrousos GP. The hypothalamicpituitary-adrenal axis in asthmatic children. Trends Endocrinol Metab. 2008; 19(1):32-8 